\title{
In vitro and in vivo evaluation of pharmacological potential of Begonia barbata Wall
}

\author{
Mohammad Rashedul Haque* (D), Mirazul Islam and Md. Ruhul Kuddus
}

\begin{abstract}
Background: Begonia barbata Wall is an important medicinal plant in Bangladesh used to treat several human diseases. The intention of the existing work was to determine in vitro and in vivo pharmacological properties of petroleum-ether, dichloromethane, and ethyl acetate soluble fractions of methanol extract of $B$. barbata whole plant (MEBB). The total phenolic content (TPC) was determined by Folin-Ciocalteu test while antioxidant activity assay was performed by DPPH radical quenching process. Tail immersion and acetic acid-induced writhing methods were utilized to evaluate analgesic effect in albino mice. To evaluate the hypoglycemic potential, glucose tolerance test is used. Castor oil-induced diarrhea method is utilized to figure out the anti-diarrheal action in mice.

Thiopental-sodium-induced sleeping time test was exploited for the appraisal of CNS antidepressant action.

Results: Antioxidant activities of the test materials followed the order: dichloromethane fraction (DCMF) > ethyl acetate fraction (EAF) > petroleum-ether fraction (PEF). The EAF yielded maximum amount of phenolic compounds (12.47 mg of GAE/g of sample). The DMF was most effective in terms of thrombolytic activity while the EAF protected the membrane integrity of erythrocyte by $63.47 \%$ inhibition of hemolysis induced by heat. Among all fractions, the PEF ( $400 \mathrm{mg} / \mathrm{kg}$ body weight) demonstrated highest analgesic activity in both tail immersion test (maximum elongations as 262.053\%) and acetic acid-induced writhing method (66.02\% writhing inhibition). During anti-diarrheal test, the plant samples significantly diminished the frequency of diarrheal episodes in mice. Similarly, the plant samples decreased the sleeping duration induced by thiopental sodium.
\end{abstract}

Conclusion: The above outcome exposed that B. barbata possesses significant pharmacological potential, which validates its use in Bangladesh folk medicinal practices.

Keywords: Analgesic, Anti-diarrheal, Antioxidant, Begonia barbata, CNS antidepressant, Hypoglycemic, Membranestabilizing, Thrombolytic

\section{Background}

Medicinal plants are vital sources of novel compounds with persuasive pharmacological actions $[1,2]$. Since ancient times, people have been exploring the medicinal plants in search of new therapeutic agents. Nearly $80 \%$ of the population in the world depends on herbal medicines for their primary health care, most of which involve the use of plant parts or unpurified plant extracts

* Correspondence: haquemr@du.ac.bd

Phytochemical Research Laboratory, Department of Pharmaceutical

Chemistry, Faculty of Pharmacy, University of Dhaka, Dhaka 1000, Bangladesh
$[3,4]$. The medicinal value of the plant extracts lies in bioactive phytoconstituents that exert a specific pharmacological action on the biological system $[2,5]$.

Bangladesh is a prominent heritage of over 500 medicinal plant species. The rural community has long tradition to exploit the medicinal value of those plants for their basic healthcare management. About 250 medicinal plants are used for preparing herbal formulations [6]. Nonetheless, the best part of these plants has been remaining as undiscovered. Therefore, in continuation of our pharmacological study on plants used in traditional

\section{Springer Open}

(ㅇ The Author(s). 2020 Open Access This article is licensed under a Creative Commons Attribution 4.0 International License, which permits use, sharing, adaptation, distribution and reproduction in any medium or format, as long as you give appropriate credit to the original author(s) and the source, provide a link to the Creative Commons licence, and indicate if changes were made. The images or other third party material in this article are included in the article's Creative Commons licence, unless indicated otherwise in a credit line to the material. If material is not included in the article's Creative Commons licence and your intended use is not permitted by statutory regulation or exceeds the permitted use, you will need to obtain permission directly from the copyright holder. To view a copy of this licence, visit http://creativecommons.org/licenses/by/4.0/. 
medicine in Bangladesh [7-9], we have selected a traditionally important medicinal plant, Begonia barbata Wall for further pharmacological investigation.

Begonia barbata Wall (syn. Begonia annulata; Bengali name: biri gach) is a type of perennial plant, a member of the Begoniaceae family which is a family of flowering plants with two genera Begonia and Hillebrandia. The genus Begonia is the largest comprising of around 1400 species with worldwide distribution. There is a record for a total of eight plants of Begoniaceae family in Bangladesh, all of which belong to the Begonia genus [10]. In our country, the plant is available in the hilly area of Chittagong, Rangamati, Bandarban, Khagrachari, and Sylhet. In India, it is mainly found in Khasi hills of Assam, Tripura, and Mizoram. The indigenous people in Chittagong Hill Tracts, Bangladesh use the whole plant to treat irregular menstruation, dysmenorrhea, and headache [11]. Leaf and stem of B. barbata is used by the local people or snake charmers (Ozha) in Chittagong Hill Tracts to treat snakebite [12].

However, to the best of our knowledge, the plant B. barbata has not yet been scientifically explored for its phytochemical as well as pharmacological activities to ensure its medicinal properties. That is why the current study was carried out to explore the pharmacological properties of B. barbata using both in vitro and in vivo model.

\section{Methods}

Collection, authentication, and extraction process of plant sample

The whole plant of Begonia barbata was collected from Moulvibazar Hill Tracts, Bangladesh, and was taxonomically identified (DACB-43432) by a scientific officer in Bangladesh National Herbarium. The collected plant samples were washed with water followed by air drying for several days. The dried plant parts were then turned into a fine powder. The powdered sample was macerated in methanol for 7 days. The filtrate was concentrated to dryness using a rotary evaporator. Following the technique of solvent-solvent partitioning protocol [13], the dried methanol extract of $B$. barbata (MEBB) was fractionated with petroleum-ether, dichloromethane, and ethyl acetate successively to separate the compounds in extracts according to their polarity. All these plant samples, PEF, DCMF, and EAF were analyzed for the assessment of the pharmacological properties of B. barbata.

\section{Chemicals and reagents}

Ascorbic acid, streptokinase, acetylsalicylic acid, morphine, diclofenac sodium, glibenclamide, fluoxetine, thiopental sodium, and loperamide were collected from Square Pharmaceuticals Ltd. and Beximco Pharmaceuticals Ltd., Bangladesh. All reagents and chemicals such as gallic acid, 2,2-diphenyl-1-picrylhydrazyl (DPPH), tert- butyl-1-hydroxytoluene (BHT), vincristine sulfate, acetic acid, and Tween 80 were of analytical grade.

\section{TPC (total phenolic content) analysis}

The amount of phenolic compound was determined for each plant sample using Folin-Ciocalteu method [14]. The absorbance was recorded using the UV-Vis spectrophotometer at $760 \mathrm{~nm}$. Gallic acid solution was prepared to construct a calibration curve. The amount of phenolic compound was expressed as milligram of gallic acid equivalent (GAE)/g of dry extract.

\section{Antioxidant activity assay}

The antioxidant activity of plant extract was estimated by DPPH scavenging assay by the protocol of BrandWilliams et al. [15]. Briefly, $3.0 \mathrm{ml}$ solution of DPPH in methanol $(20 \mu \mathrm{g} / \mathrm{mL})$ was mixed with plant samples at different concentrations (500.0 to $0.977 \mu \mathrm{g} / \mathrm{mL}$ ). The reaction mixture was vortex and was left in the dark for $30 \mathrm{~min}$. Then, a UV-Vis spectrophotometer was used to measure the absorbance value of each mixture at 517 $\mathrm{nm}$. The percentage of inhibition (I\%) was measured against blank:

$$
(I \%)=\frac{A_{\text {blank }}-A_{\text {sample }}}{A_{\text {blank }}} \times 100 \%
$$

where $A$ is the absorbance for each group. After that, the $\mathrm{IC}_{50}$ value (50\% inhibition) for each plant sample was estimated from a graph of \% inhibition of DPPH scavenging vs. concentration of the test materials.

\section{Thrombolytic activity}

The clot lysis ability of the extract was tested following an established protocol [16] where streptokinase (SK) was used as standard. One milliliter of human blood was transferred to clean Eppendorf tubes which were then kept at room temperature until blood clot forms. The serum was finally removed from the clot. The weight of the clot formed in Eppendorf tube was obtained by subtracting the weight of the tube alone from the weight of clot-containing tube. The plant sample was added individually to the blood clot in each tube, followed by incubation at room temperature for $90 \mathrm{~min}$ to examine the clot lysis. The free liquid after incubation was decanted and the tubes were once more weighted to monitor the weight variation before and after clot lysis. The weight variation which was expressed as percentage of clot lysis is calculated by following the underneath equation: 


$$
\% \text { clot lysis }=\frac{\text { Weight of the lysis clot }}{\text { Weight of clot before lysis }} \times 100 \%
$$

\section{Membrane stabilizing effect}

The test materials were subjected to evaluate the membrane-stabilizing activity against heat- and hypotonic solution-induced hemolysis of human blood [17].

\section{Animals}

Swiss albino mice were kept under regular laboratory environment with $12 \mathrm{~h}$ dark and $12 \mathrm{~h}$ light cycle. The study protocol was permitted by the Institutional Animal Ethics Committee [18].

\section{Animal experimental design}

For in vivo experiment, albino mice were divided into the following groups with three mice each. Group I serving as negative control received the vehicle (1\% Tween $80+$ normal saline), group II (positive control) was treated with standard drug for the respective experiment. Groups III and IV received PEF (200 and 400-mg/kg); groups V and VI received DCMF (200 and $400 \mathrm{mg} / \mathrm{kg}$ ); and group VII and VIII were loaded with EAF (200 and $400 \mathrm{mg} / \mathrm{kg}$ ).

\section{Analgesic activity \\ Tail immersion test}

Central analgesic activity of the plant extracts was determined by the tail-immersion procedure in Swiss albino mice [19]. For this test, the animals were treated orally with the soluble fractions of MEBB at a dose of 200 and $400 \mathrm{mg} / \mathrm{kg}$ body weight. After treatment, the tail of each of the mice up to $5 \mathrm{~cm}$ was then dipped into a water bath maintained at $55 \pm 0.1^{\circ} \mathrm{C}$. The time taken for the mouse to withdraw the tail in seconds was considered as the pain reaction time (PRT) and was measured at 0,30 , 60 , and 90 min following the loading of the test samples. Finally, the percentage of time elongation of tail immersion was calculated in respect to standard morphine by the equation below.

$$
\% \text { time elongation }=\frac{T_{\text {test }}-T_{\text {control }}}{T_{\text {control }}} \times 100 \%
$$

Here $T_{\text {test }}$ is the pain reaction time for the test group and $T_{\text {control }}$ is the pain reaction time for the control group.

\section{Acetic acid writhing test}

The peripheral analgesic activity of B. barbata was evaluated by acetic acid abdominal constriction tests [20, 21]. Like the tail-immersion test, both standard diclofenac sodium and plant samples were administered to the experimental animals by oral route. Forty minutes after the administration of all treatments, $1 \%$ acetic acid was injected intraperitoneally to each animal to induce the writhing (abdominal constrictions). Ten minutes after acetic acid injection, the number of writhing was counted for $5 \mathrm{~min}$ for each mouse. The plant sample possessing analgesic activity will decrease the number of writhing in animals. The percentage of writhing inhibition of the treated group was then calculated by using the following equation:

$$
\text { \%inhibition of writhing }=\frac{N_{\text {Control }}-N_{\text {Test }}}{N_{\text {Control }}} \times 100 \%
$$

where $N$ is the mean number of writhing for each group.

\section{Hypoglycemic effect}

Glucose tolerance test is employed to evaluate the hypoglycemic effect of B. barbata in mice model [22]. Briefly, 30 min after oral administration of plant extract/ drug, a $10 \%$ glucose solution was given orally to mice of all test groups. Then blood glucose level was recorded by glucometer for each animal prior to administration of extract/drug (at $0 \mathrm{~min}$ ) and then at 1,2 , and $3 \mathrm{~h}$ after the glucose load. The percent reduction in blood glucose level of $B$. barbata can be estimated by the equation below:

$$
\% \text { reduction in blood glucose }=\frac{B G_{\text {control }}-B G_{\text {test }}}{B G_{\text {control }}} \times 100 \%
$$

where BG is the average blood glucose level for each group.

\section{Anti-diarrheal effect}

The plant samples were also subjected to verify the antidiarrheal effect in mice by castor oil-induced diarrhea model $[23,24]$. Briefly, $30 \mathrm{~min}$ after the administration of the respective doses and treatments, $0.5 \mathrm{ml}$ castor oil was injected to induce diarrhea in each mouse. Antidiarrheal effect of the plant sample was observed for $4 \mathrm{~h}$. The percent reduction in frequency of defecation by the test samples was determined according to the equation:

$$
\text { \%inhibition of defecation }=\frac{D_{\text {control }}-D_{\text {test }}}{D_{\text {control }}} \times 100 \%
$$

where $D$ is the mean number of diarrheal episode in each group.

\section{Anxiolytic effect}

Thiopental sodium-induced sleeping time test was conducted to estimate the anxiolytic potential of $B$. barbata in albino mice [25]. Thirty minutes after loading of plant samples and standard fluoxetine orally, each mouse was induced to sleep by thiopental sodium. Then, the 
anxiolytic effect was evaluated through the estimation of percent inhibition of sleeping time using the equation:

$$
\text { \%inhibition of sleeping time }=\frac{T_{\text {control }}-T_{\text {test }}}{T_{\text {control }}} \times 100 \%
$$

where $T$ is the average sleeping time in each group.

\section{Results}

Table 1 shows the total phenolic content, TPC in the PEF, DCMF, and EAF. The amount of phenolic compound in these soluble fractions of MEBB was estimated via Folin-Ciocalteu assay using a standard curve which was prepared by gallic acid with diverse concentration. Among all, the maximum yield of phenolic compound was observed in EAF (12.47 mg of GAE/g of dry extract) followed by DCMF (12.47 mg of GAE/g of dry extract).

During antioxidant assay, Fig. 1 showed the concentration-dependent percentage inhibition of samples on DPPH radical (Fig. 1a) and $\mathrm{IC}_{50}$ values of PEF, DCMF, EAF, and standard AA, BHT (Fig. 1b). The $\mathrm{DPPH}$ radical scavenging effect of the test samples were in the following order: DMF $\left(\mathrm{IC}_{50}=6.22 \mu \mathrm{g} / \mathrm{mL}\right)>\mathrm{EAF}$ $\left(\mathrm{IC}_{50}=8.29 \mu \mathrm{g} / \mathrm{mL}\right)>\operatorname{PEF}\left(\mathrm{IC}_{50}=29.92 \mu \mathrm{g} / \mathrm{mL}\right)$. The plant extract with the lower $\mathrm{IC}_{50}$ value has proficient antioxidant capacity. Both the DCMF and EAF showed superior DPPH radical-scavenging effect, perhaps due to the occurrence of the maximum quantity of phenolic compounds found in these two samples (Table 1).

The clot lysis ability of plant extracts was determined as a part of searching of cardiovascular agents from plant sources and the conclusion is summarized in Fig. 2. Addition of SK (30,000 I.U.) to the human blood clots along with incubation at $37^{\circ} \mathrm{C}$ for $90 \mathrm{~min}$, exhibited $68.22 \%$ clot lysis. At $10 \mathrm{mg} / \mathrm{ml}$ concentration of DMF, PEF, and EAF showed 24.95\%, 23.48\%, and $17.41 \%$ clot lysis activity, respectively comparing with $5.35 \%$ clot lysis displayed by a negative control.

The different soluble fractions derived from the methanol extract of B. barbata were subjected to assay for membrane stabilizing potential following standard protocols and the obtained results were represented in Fig. 3. At $2.0 \mathrm{mg} / \mathrm{mL}$, the plant samples of $B$. barbata significantly inhibited the hemolysis of RBC induced by heat and hypotonic solution, as compared to the standard ASA (Fig. 3). In heat-induced hemolysis model, the EAF and DMF confirmed $63.47 \%$ and $60.21 \%$ inhibition of hemolysis of human RBCs, respectively, compared to

Table 1 Total phenolic content of PEF, DCMF, and EAF

\begin{tabular}{ll}
\hline Plant sample & TPC $(\mathbf{m g}$ of GAE/g of dry extract) \\
\hline PEF & 7.13 \\
DCMF & 10.26 \\
EAF & 12.47 \\
\hline
\end{tabular}

reference ASA (42.57\% inhibition of hemolysis). However, in case of hypotonic solution-induced hemolysis, these solvent fractions showed fairly lesser protective action in comparison to the level of inhibition, which was noticed during heat-induced situation.

The results of the tail-immersion test of B. barbata and standard morphine in albino mice are summarized in Table 2. In this test, PEF, DMCF, and EAF induced a remarkable reduction in the painful feeling when compared to control. The percent (\%) elongation was monitored at 30,60, and $90 \mathrm{~min}$ following the loading of drug/extract in mice. Among the extractives, the PEF exhibited maximum elongations as $262.053 \%$ after $90 \mathrm{~min}$ and this result was as good as to the reference drug (508.32\%).

In the acetic acid-induced writhing method, all the plant samples (200 and $400 \mathrm{mg} / \mathrm{kg}$ ) markedly exhibited dose-dependent reduction in the number of abdominal writhes in animals when judged against the control group. The test materials at the dose of $400 \mathrm{mg} / \mathrm{kg}$ induced a dose-dependent increase in writhing inhibition, raising it from $0 \%$ in the control group to $66.02 \%$, $64.16 \%$, and $52.83 \%$ by PEF, DCMF, and EAF of B. barbata, respectively, in comparison to diclofenac sodium (69.82\% inhibition) (Table 3).

In the glucose tolerance test, oral administration of test samples demonstrated significant hypoglycemic activity in mice when compared to standard glibenclamide. The DCMF (200 and $400 \mathrm{mg} / \mathrm{kg}$ ) demonstrated utmost activity which continues up to the $2 \mathrm{~h}$ after treatment (Table 4).

During the anti-diarrheal test, the tested fractions (200 and $400 \mathrm{mg} / \mathrm{kg}$ ) confirmed a noticeable and dosedependent anti-diarrheal effect in animals (Table 5). Oral administration of castor oil in mice provoked diarrhea, which continues up to $4 \mathrm{~h}$ in the control mice. The diarrheal episode was inhibited by $44.98 \%, 59.97 \%$, $50.07 \%$, and $55.02 \%$, respectively, of both PEF and EAF at doses, 200 and $400 \mathrm{mg} / \mathrm{kg}$.

Thiopental sodium-induced sleeping time test was employed to evaluate the CNS antidepressant activity of $B$. barbata. The soluble fractions of B. barbata are proficient to decrease the length of sleep induced by thiopental sodium in mice. Among all, the PEF at both doses showed maximum antidepressant activity in mice (Fig. 4).

\section{Discussion}

Phenolic components are plant-derived secondary metabolites, which can work as antioxidants by various potential mechanisms [26, 27]. The hydroxyl group of polyphenols can scavenge free radicals such as hydroxyl radical $(\mathrm{OH}$.$) and hydrogen peroxide \left(\mathrm{H}_{2} \mathrm{O}_{2}\right)$, which are well reported to aggravate oxidative stress in biological 


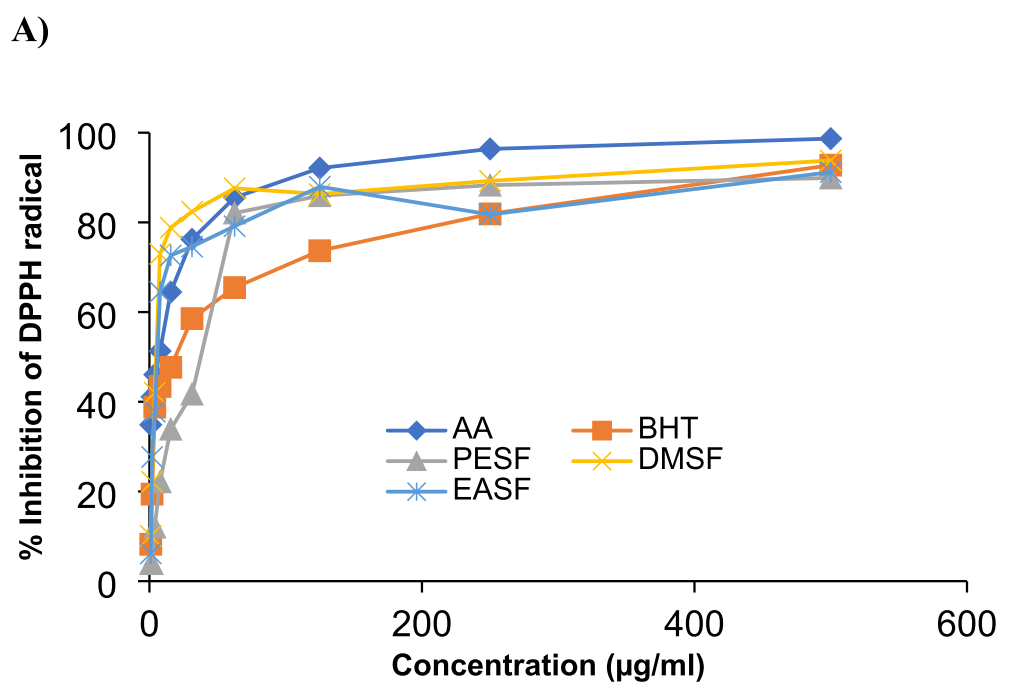

B)

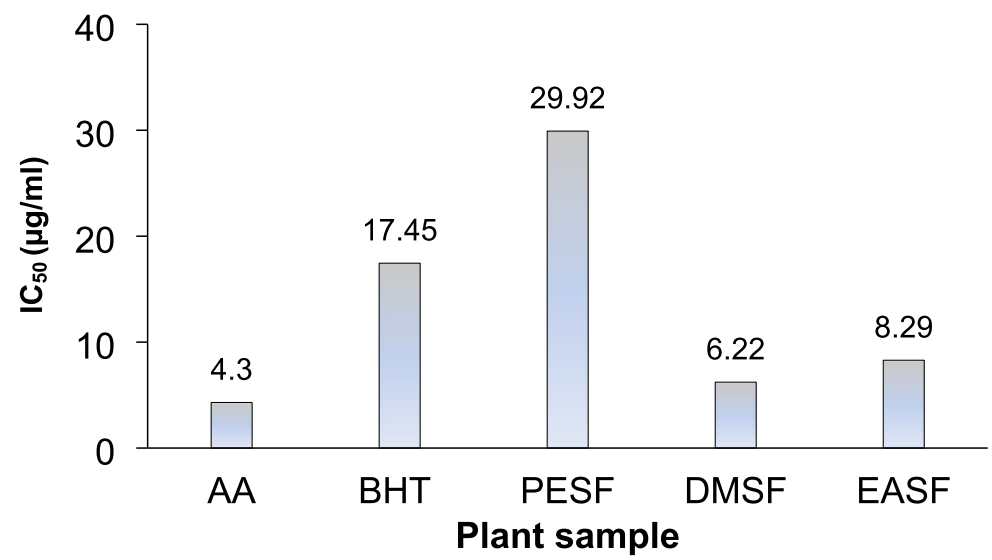

Fig. 1 Determination of (a) DPPH radical scavenging activity and (b) IC 50 of PEF, DMF, EAF, and standards

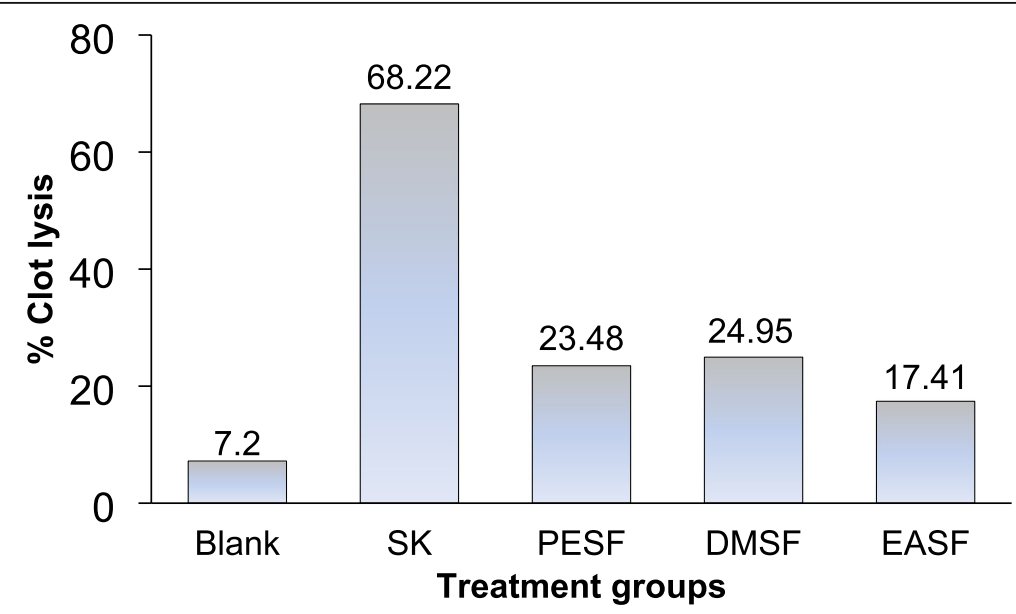

Fig. 2 Percentage of clot lysis activity of PEF, DMF, and EAF along with streptokinase (SK) 


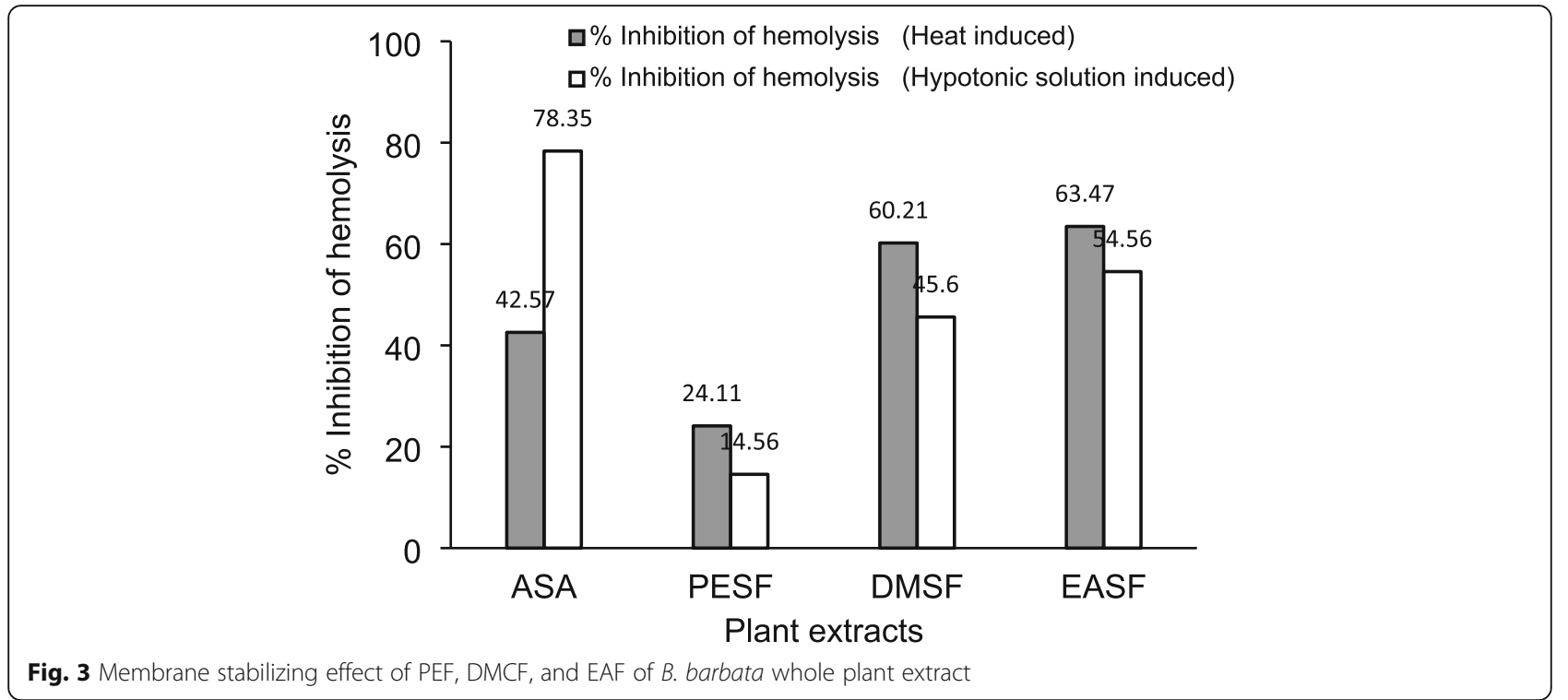

system [28]. During TPC analysis, a reasonable amount of phenolics was extracted from the ethyl acetate and dichloromethane soluble fractions of methanol extracts of B. barbata.

DPPH scavenging assay is the most frequently employed method intended for evaluating the antioxidant potential of plant samples [29]. The antioxidant activity on DPPH is thought to be because of their hydrogen donating capacity [30]. It is well reported that the generation of free radicals in the body causes cell and tissue damage leading to the pathological situations as cancer, diabetes, and neurodegenerative. Antioxidants possessing free radical quenching potential have vast importance in the management of this pathological condition. That is why there is a rising interest in finding natural antioxidants from plant extracts that could avert free radical induced-oxidative damage in the body [31]. In our study, the tested samples of B. barbata having

Table 2 Effect of PEF, DMF, and EAF on tail-immersion model in mice

\begin{tabular}{llll}
\hline Treatment & \multicolumn{3}{l}{ \% Time elongation } \\
\cline { 2 - 4 } & \multicolumn{3}{l}{ Time after loading the plant sample/drug } \\
\cline { 2 - 4 } & $\mathbf{3 0} \mathbf{~ m i n}$ & $\mathbf{6 0}$ min & $\mathbf{9 0 ~} \mathbf{m i n}$ \\
\hline Standard $(2 \mathrm{mg} / \mathrm{kg})$ & 75.409 & 334.328 & 508.929 \\
PEF $(200 \mathrm{mg} / \mathrm{kg})$ & 56.148 & 126.866 & 204.910 \\
PEF $(400 \mathrm{mg} / \mathrm{kg})$ & 80.328 & 170.647 & 262.053 \\
DCMF $(200 \mathrm{mg} / \mathrm{kg})$ & 24.180 & 181.592 & 176.339 \\
DCMF $(400 \mathrm{mg} / \mathrm{kg})$ & 54.098 & 162.189 & 240.179 \\
EAF $(200 \mathrm{mg} / \mathrm{kg})$ & 36.475 & 125.373 & 192.411 \\
EAF $(400 \mathrm{mg} / \mathrm{kg})$ & 52.869 & 186.567 & 205.357 \\
\hline
\end{tabular}

moderate amount of phenolic compounds can serve as antioxidant agents through the mechanism of radical quenching power. Moreover, our results also established a positive connection between total phenolic content and DPPH radical quenching capacity [32].

Previously several research works have been conducted with Bangladeshi medicinal plants to find out the natural compounds with antithrombotic potential $[33,34]$. Therefore, in quest of thrombolytic products from plant source, in this study, we have selected a Bangladeshi medicinal plant, B. barbata for screening of thrombolytic potential. The present study demonstrated that the soluble fractions of $B$. barbata have significant thrombolytic effect since it effectively reduces the weight of blood clot in our experimental conditions. Our results may signify the opportunity of developing new thrombolytic agents from $B$. barbarata extracts.

Table 3 Effect of PEF, DCMF, and EAF on acetic acid-induced writhing method in mice

\begin{tabular}{|c|c|c|c|c|c|}
\hline \multirow[t]{2}{*}{ Treatment } & \multicolumn{3}{|c|}{ Writhing count } & \multirow{2}{*}{$\begin{array}{l}\text { Average } \\
\text { writhing }\end{array}$} & \multirow{2}{*}{$\begin{array}{l}\% \\
\text { Inhibition } \\
\text { of } \\
\text { writhing }\end{array}$} \\
\hline & M-1 & $M-2$ & $M-3$ & & \\
\hline Control (1\% Tween 80) & 17 & 19 & 17 & 17.66 & - \\
\hline Standard (50 mg/kg) & 4 & 5 & 7 & 5.33 & 69.82 \\
\hline PEF (200 mg/kg) & 14 & 10 & 10 & 11.33 & 35.84 \\
\hline PEF (400 mg/kg) & 7 & 6 & 5 & 6 & 66.02 \\
\hline DCMF $(200$ mg/kg) & 8 & 7 & 10 & 8.33 & 52.83 \\
\hline DCMF (400 mg/kg) & 5 & 9 & 5 & 6.33 & 64.16 \\
\hline EAF $(200$ mg/kg) & 9 & 14 & 10 & 11 & 37.72 \\
\hline EAF $(400$ mg/kg) & 10 & 8 & 7 & 8.33 & 52.83 \\
\hline
\end{tabular}


Table 4 Effect of PEF, DMF, and EAF on blood glucose level in mice

\begin{tabular}{llll}
\hline Treatment & \multicolumn{3}{l}{ \% Reduction of blood glucose level } \\
\cline { 2 - 4 } & \multicolumn{1}{l}{ Hour after administration of plant sample/drug } & $\mathbf{3} \mathbf{~}$ \\
\cline { 2 - 4 } & 33.93 & 24.28 & 39.79 \\
\hline Glibenclamide $(2 \mathrm{hg} / \mathrm{kg})$ & 37.49 & 23.49 & 2.65 \\
PEF $(200 \mathrm{mg} / \mathrm{kg})$ & 26.45 & 35.51 & 16.98 \\
PEF $(400 \mathrm{mg} / \mathrm{kg})$ & 39.50 & 20.89 & 38.99 \\
DCMF $(200 \mathrm{mg} / \mathrm{kg})$ & 35.11 & 29.50 & 28.38 \\
DCMF $(400 \mathrm{mg} / \mathrm{kg})$ & 17.32 & 32.90 & 10.61 \\
EAF $(200 \mathrm{mg} / \mathrm{kg})$ & 29.18 & 7.57 & 7.96 \\
EAF $(400 \mathrm{mg} / \mathrm{kg})$ & & & \\
\hline
\end{tabular}

Membrane stabilization assay is a common technique used to explore the plant extracts for natural products with anti-inflammatory potential [35]. Exposure of RBC to heat and hypotonic solution results in the hemolysis of RBC [36]. So, the test materials having membranestabilizing effect might be suitable as anti-inflammatory agents [17]. In this study, various organic soluble fractions of the methanolic extract of $B$. barbata significantly protected the integrity of the $\mathrm{RBC}$ membrane against the stressful conditions such as heat and hypotonic solution. Therefore, B. barbata might be considered as a good source of anti-inflammatory agents.

Analgesic agents are being searched from natural sources as alternatives to synthetic drugs because they have little side effects [37]. Therefore, it is imperative to find out plant-based pain-relieving agents possessing no adverse effects. In our study, a centrally acting tail immersion model and peripherally acting acetic acidinduced writhing test were utilized to determine the analgesic effect of $B$. barbata. All the plant extracts were well capable to decrease the level of pain sensation in mice against both heat and acetic acid-induced stimuli. The tail immersion method has been employed extensively for the assessment of compounds generating analgesia by central mechanism is believed to raise the pain threshold of experimental animal toward heat [38]. In the current experiment, the test materials of B. barbata demonstrated a noticeable reduction of pain in albino mice, which is comparable to standard drug morphine. Therefore, the analgesic effect exhibited by the test samples in the tail-immersion model indicates the plausible contribution of the opioid receptors in the brain center.

Intra-peritoneally administered acetic acid elevates the production of prostaglandin-like mediators in the peritoneal fluid which ultimately leads to inflammation in mice $[39,40]$. The plant extracts appreciably repressed the number of abdominal writhes in mice. The results suggest that the soluble fractions of $B$. barbata may contain bioactive components which when administered leads to reduce pain sensation through the inhibition of prostaglandin synthesis. Further laboratory studies are essential to find out the responsible compounds.

In recent years, the prevalence of diabetes mellitus is increasing throughout the world. Therefore, various researches are going on to discover better hypoglycemic agents from natural sources to avoid the side effects associated with synthetic drug [41]. The present study deals with an introductory work about the hypoglycemic effect of $B$. barbata in mice model. During the glucose tolerance test, the soluble fractions of $B$. barbata showed a remarkable hypoglycemic action in mice which continue up to $2 \mathrm{~h}$ compared to standard glibenclamide. Therefore, the hypoglycemic effect exhibited by the selected plant may be attributed to the several important bioactive phytoconstituents such as flavonoids, tannins, and alkaloids [42].

Table 5 Anti-diarrheal effect of PEF, DMF, and EAF by castor oil-induced diarrhea in mice

\begin{tabular}{|c|c|c|c|c|}
\hline \multirow[t]{3}{*}{ Treatment } & \multicolumn{4}{|c|}{$\%$ Reduction in the frequency of diarrheal episode } \\
\hline & \multicolumn{4}{|c|}{ Hour after administration of plant sample/drug } \\
\hline & $1 \mathrm{~h}$ & $2 \mathrm{~h}$ & $3 \mathrm{~h}$ & $4 \mathrm{~h}$ \\
\hline Loperamide (50 mg/kg) & 100 & 90.09 & 85.65 & 74.96 \\
\hline PEF (200 mg/kg) & 49.62 & 69.97 & 57.17 & 44.98 \\
\hline PEF $(400$ mg/kg) & 100 & 79.88 & 71.52 & 59.97 \\
\hline EAF $(200$ mg/kg) & 24.81 & 69.97 & 57.17 & 50.07 \\
\hline EAF $(400$ mg/kg) & 75.18 & 69.97 & 50.11 & 55.02 \\
\hline
\end{tabular}




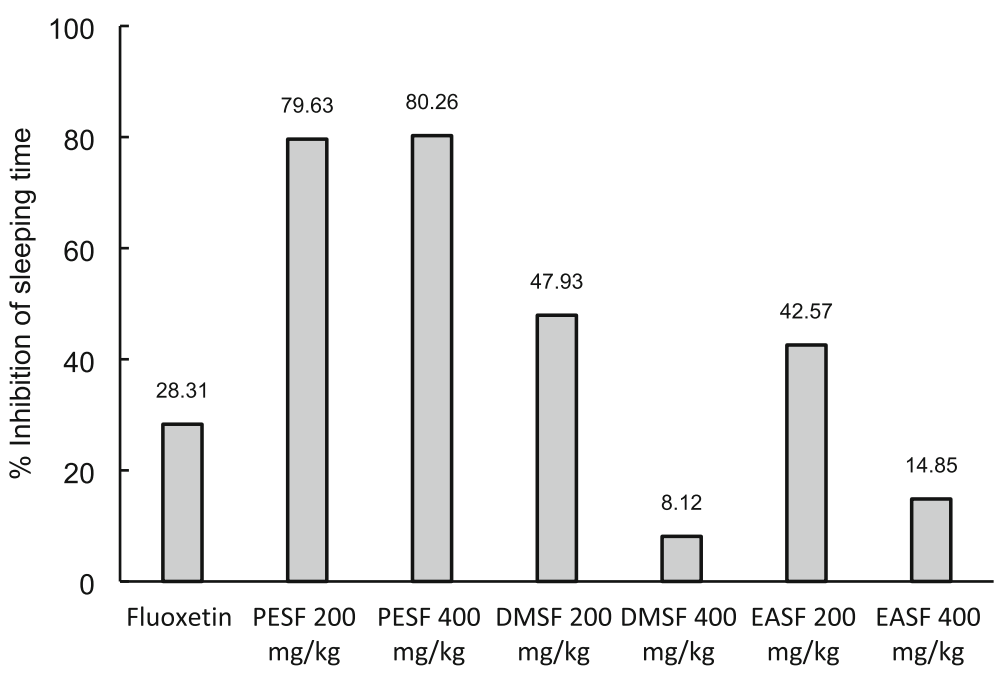

Fig. 4 Antidepressant effects of PEF, DCMF, EAF, and fluoxetin by thiopental sodium-induced sleeping model

The test samples of B. barbata inhibited castor oilinduced diarrhea in mice. Castor oil induces secretory diarrhea in mice via its active ingredient ricinoleic acid. Liberation of ricinoleic acid in the small intestine stimulates the GI motility which ultimately induces diarrhea in mice [43]. The capacity of B. barbata to decrease the diarrheal episode in mice might be mediated by the bioactive phytochemicals present in B. barbata [44].

During the evaluation of CNS antidepressant property, the administration of $B$. barbata extract produced notable antidepressant activities. CNS antidepressant action of $B$. barbata may be due to the phytochemical composition of the extract $[45,46]$.

\section{Conclusion}

Begonia barbata is an important medicinal plant to the indigenous people in Chittagong Hill Tracts, Bangladesh. According to our primary study results, it can be suggested that $B$. barbata possesses prominent pharmacological potential, which substantiate its use in traditional medicine. However, additional inclusive research is needed to isolate potential phytoconstituents and recognize the original mechanisms.

\section{Abbreviations}

PESF: Petroleum-ether fraction; DMSF: Dichloromethane fraction; EASF: Ethyl acetate soluble fractions; TPC: Total phenolic content; DPPH: 2,2-diphenyl-1picrylhydrazyl; BHT: Tert-butyl-1-hydroxytoluene; MEBB: Methanolic extract of B. barbata; GAE: Gallic acid equivalents; SK: Streptokinase; AA: Ascorbic acid; ASA: Acetyl salicylic acid

\section{Acknowledgements}

The authors are grateful to Bangladesh National Herbarium, Mirpur, Dhaka, for plant identification.

\section{Authors' contributions}

Ml participated in the conduction of the experiments. Data interpretation and analysis were done by MI, MRK and MRH. MRK and MI participated in drafting the manuscript. MRK and MRH finally revised the manuscript for important intellectual content. MRH supervised and designed the study and corrected all versions of the manuscript. All authors read and approved the final manuscript.

\section{Funding}

This research did not receive any specific grant from funding agencies in the public, commercial, or not-for-profit sectors.

\section{Availability of data and materials}

The datasets supporting the conclusions of this article are included within the article. Data and materials are available upon request.

\section{Ethics approval and consent to participate}

All experiments were conducted in accordance with the ethical standards laid down in the Declaration of Helsinki 2013. Animals were handled and treated according to the principles of the Swiss Academy of Medical Sciences and the Swiss Academy of Sciences. Animals were euthanized according to the Guidelines for the Euthanasia of Animals: 2013 edition. The protocols of experiments were approved by the Research Ethics Committee, Faculty of Pharmacy, University of Dhaka (dated 17 December 2018, no approval number is given by the ethics committee). The authors gave consent to participate in the experiment.

\section{Consent for publication}

Not applicable.

\section{Competing interests}

The authors declare that they have no competing interests.

Received: 26 July 2020 Accepted: 12 October 2020

Published online: 28 November 2020

\section{References}

1. Ghani A (1997) Medicinal Plants of Bangladesh-Chemical Constituents and Uses. Asiatic Society, Dhaka, Bangladesh, p 460

2. Rashid MA, Haque MR, Sikder MA, Chowdhury AA, Rahman MS, Hasan, C (2015) Review on chemistry and bioactivities of secondary metabolites from some medicinal plants and microbes of Bangladesh. Bangladesh Pharm J 17:1-17 https://doi.org/https://doi.org/10.3329/bpj.v17i1.22307.

3. Cragg GM, Newman DJ (2013) Natural products: a continuing source of novel drug leads. Biochim Biophys Acta 1830:3670-3695 https://doi.org/ https://doi.org/10.1016/j.bbagen.2013.02.008.

4. Martins E (2014) The growing use of herbal medicines: issues relating to adverse reactions and challenges in monitoring safety. Front Pharmacol 4:110 https://doi.org/https://doi.org/10.3389/fphar.2013.00177. 
5. Rahman S, Hasnat A, Hasan CM, Rashid MA, llias M (2001) Pharmacologica evaluation of Bangladeshi medicinal plants-a review. Pharma Biol 39: 1-6 https://doi.org/https://doi.org/10.1076/phbi.39.1.1.5939.

6. Uddin SJ, Grice ID, Tiralongo E (2011) Cytotoxic effects of Bangladeshi medicinal plant extracts. Evid Based Complement Altern Med 2011:578092 https://doi.org/https://doi.org/10.1093/ecam/nep111.

7. Islam M, Jannat T, Kuddus MD, Rashid MA, Haque, MR (2019) In vitro and in vivo evaluation of pharmacological potentials of Campsis radicans L. Clinical Phytosci 5:42 https://doi.org/https://doi.org/10.1186/ s40816-019-0144-9.

8. Arif M, Kuddus MR, Islam MT, Ibrahim M (2019) Evaluation of in vivo and in vitro biological activities of Gardenia latifolia Ait leaf. GSC Biol Pharm Sci 7(03): 116-123 https://doi.org/https://doi.org/10.30574/gscbps.2019.7.3.0097.

9. Moniruzzaman M, Kuddus MR, Chowdhury AMS and Rashid MA (2019) Antioxidant, antimicrobial, anti-diarrheal and analgesic activities of Diospyros malabarica (Desr.) Kostel. Bangladesh Pharm J 22(1):27-33 https://doi.org/ https://doi.org/10.3329/bpj.v22i1.40022.

10. Ahmed ZU, Hassan MA, Begum ZNT, Khondker M, Kabir SMH, Ahmad M, Ahmad ATA, Rahman AKA, Haque EU (2008) Encyclopedia of flora and fauna of Bangladesh, Vol. 7.Angiosperms: Dicotyledons (BalsaminaceaeEuphorbiaceae). Asiatic Society of Bangladesh, Dhaka, p 546

11. Hossan MS, Roy P, Seraj S, Mou SM, Monalisa MN, Jahan S, Khan T, Swarna A, Jahan R. Rahmatullah M (2012) Ethnomedicinal knowledge among the Tongchongya tribal community of Roangchaari Upazila of Bandarban district, Bangladesh. Am Eurasian J Sustain Agric 6(4):349-359.

12. Kadir MF, Karmoker JR, Alam MR, Jahan SR, Mahbub S, Mia MMK (2015) Ethnopharmacological survey of medicinal plants used by traditional healers and indigenous people in Chittagong Hill Tracts, Bangladesh, for the treatment of snakebite. Evid Based Complement Altern Med http://dx.doi. org/https://doi.org/10.1155/2015/871675.

13. Van-Wagenen BC, Larsen R, Cardellina JH, Randazzo D, Lidert ZC, Swithenbank C (1993) Ulosantion, a potent insecticide from the sponge Ulosa ruetzleri. J Organomet Chem 58:335-337 https://doi.org/https://doi. org/10.1021/j000054a013.

14. Saeed N, Khan MR, Shabbir M (2012) Antioxidant activity, total phenolic and total flavonoid contents of whole plant extracts Torilis leptophylla L. BMC Complement Altern Med 12:221 https://doi.org/https://doi.org/10.1186/ 1472-6882-12-221.

15. Brand-William W, Cuvelier ME, Berset C (1995) Use of free radical method to evaluate antioxidant activity. Lebensm-Wiss-U-Technol 28:25-30 https://doi. org/https://doi.org/10.1016/50023-6438(95)80008-5.

16. Prasad S, Kashyap RS, Deopujari JY, Purohit HJ, Taori GM, Daginawala HF (2006) Development of an in vitro model to study clot lysis activity of thrombolytic drugs. Thromb J 4:14 https://doi.org/https://doi.org/10.1186/ 1477-9560-4-14.

17. Shinde UA, Phadke AS, Nair AM, Mungantiwar AA, Dikshit VJ, Saraf MN (1999a) Membrane stabilizing activity-a possible mechanism of action for the anti-inflammatory activity of Cedrus deodara wood oil. Fitoterapia 70: 251-257 https://doi.org/https://doi.org/10.1016/50367-326X(99)00030-1.

18. Zimmermann M (1983) Ethical guidelines for investigations of experimental pain in conscious animals. Pain 16:109-110 https://doi.org/https://doi.org/10. 1016/0304-3959(83)90201-4.

19. Ezeja MI, Omeh YS, Ezeigbo II, Ekechukwu A (2011) Evaluation of the analgesic activity of the methanolic stem bark extract of Dialium guineense (wild). Ann Med Health Sci Res 1:55-62

20. Koster R, Anderson M, De Beer EJ (1959) Acetic acid for analgesic screening. Fed Proc 18:412-415

21. Adzu B, Amos S, Wambebe C, Gamaniel K (2001) Antinociceptive activity of Zizyphus spina-christi root bark extract. Fitoterapia 72 (4): 344-350 https://doi. org/https://doi.org/10.1016/s0367-326x(00)00289-6

22. Hasan MN, Rahman MH, Guo R, Hirashima A (2015) Hypoglycemic activity of methanolic leaf extract of Blumea lacera in Swiss-albino mice. Asian Pac J Trop Dis 5(3):195-198 https://doi.org/https://doi.org/10.1016/S22221808(14)60652-6.

23. Shoba FG, Thomas M (2001) Study of antidiarrhoeal activity of four medicinal plants in castor oil induced diarrhea. J Ethnopharmacol 76(1):7376 https://doi.org/https://doi.org/10.1016/s0378-8741(00)00379-2.

24. Sisay M, Engidawork E, Shibeshi W (2017) Evaluation of the anti-diarrheal activity of the leaf extracts of Myrtus communis Linn (Myrtaceae) in mice model. BMC Complement Altern Med 17:103 https://doi.org/https://doi.org/ 10.1186/s12906-017-1625-3.
25. Ashok Kumar BSA, Lakshman K, Velmurugan C, Sridhar SM, Gopisetty S (2014) Antidepressant activity of methanolic extract of Amaranthus spinosus. Basic Clin Neurosci 5:11-17

26. Dai J, Mumper RJ (2010). Plant phenolics: extraction, analysis and their antioxidant and anticancer properties. Molecules (Basel, Switzerland), 15(10): 7313-7352 https://doi.org/https://doi.org/10.3390/molecules15107313.

27. Kaur C, Kapoor HC (2002). Anti-oxidant activity and total phenolic content of some Asian vegetables. Int J Food Sci Technol 37(2):153-161 https://doi. org/https://doi.org/10.1046/j.1365-2621.2002.00552.x.

28. Karim MA, Islam MA, Islam MM, Rahman MS, Sultana S, Biswas S, Hosen MJ, Mazumder K, Rahman MM, Hasan MN (2020) Evaluation of antioxidant, antihemolytic, cytotoxic effects and anti-bacterial activity of selected mangrove plants (Bruguiera gymnorrhiza and Heritiera littoralis) in Bangladesh. Clinical Phytosci 6:8. https://doi.org/https://doi.org/10.1186/s40816-020-0152-9.

29. Akar Z, Kucuk M, Dogan H (2017) A new colorimetric DPPH scavenging activity method with no need for a spectrophotometer applied on synthetic and natural antioxidants and medicinal herbs. J Enzyme Inhib Med Chem 32(1):640-647 https://doi.org/https://doi.org/10.1080/ 14756366.2017 .1284068

30. Baumann J, Wurn G, Bruchlausen FV (1979) Prostaglandin synthetase inhibiting $\mathrm{O}_{2}$ radical scavenging properties of some flavonoids and related phenolic compounds. Arch Pharm (Weinheim) 313(4):330-337. https://doi. org/https://doi.org/10.1002/ardp.19803130409.

31. Rahman MM, Islam MB, Biswas M, Alam AHK (2015) In vitro antioxidant and free radical scavenging activity of different parts of Tabebuia pallida growing in Bangladesh. BMC Res Notes 8:621. https://doi.org/https://doi. org/10.1186/s13104-015-1618-6.

32. Huang D, Ou B, Prior RI (2005) The chemistry behind antioxidant capacity assays. J Agric Food Chem 53:1841-1856. https://doi.org/https://doi.org/10. 1021/ff030723C

33. Rahman MA, Sultana R, Bin Emran T, Islam MS, Rahman MA, Chakma JS, Rashid HU, Hasan CM (2013) Effects of organic extracts of six Bangladeshi plants on in vitro thrombolysis and cytotoxicity. BMC Complement Altern Med 13:25 https://doi.org/https://doi.org/10.1186/1472-6882-13-25.

34. Mahmud S, Akhter S, Rahman MA, Aklima J, Akhter S, Merry SR, Jubair SM, Dash R, Emran TB (2015) Antithrombotic effects of five organic extracts of Bangladeshi plants in vitro and mechanisms in in silico models. Evid Based Complement Altern Med https://doi.org/https://doi. org/10.1155/2015/782742.

35. Chaity FR, Khatun M, Rahman MS (2016) In vitro membrane stabilizing, thrombolytic and antioxidant potentials of Drynaria quercifolia L., a remedial plant of the Garo tribal people of Bangladesh. BMC Complement Alter Med 16:184. https://doi.org/https://doi.org/10.1186/s12906-016-1170-5.

36. Halliwell B, Whiteman M (2004) Measuring reactive species and oxidative damage in vivo and in cell culture: how should you do it and what do the results mean? Br J Pharmacol 142:231-255. https://doi.org/https://doi.org/10. 1038/sj.bjp.0705776.

37. Zulfiker AHM, Rahman MM, Hossain MK, Hamid K, Mazumder MEH, Rana MS (2010) In vivo analgesic activity of ethanolic extracts of two medicinal plants-Scoparia dulcis L. and Ficus racemosa Linn. Biol Med 2(2):42-48

38. Hiruma-Lima CA, Gracioso JS, Bighetti EJB, Germonsen-Robineou L, SouzaBrito ARM (2000) The juice of the fresh leaves of Boerhaavia diffusa $L$. (Nyctaginaceae) markedly reduces pain in mice. J Ethnopharmacol 71:267274 https://doi.org/https://doi.org/10.1016/s0378-8741(00)00178-1.

39. Saha S, Guria T, Singha T, Maity TK (2013) Evaluation of analgesic and antiInflammatory activity of chloroform and methanol extracts of Centella asiatica Linn. ISRN Pharmacol 2013: 789613. https:/doi.org/https://doi.org/ 10.1155/2013/789613.

40. Anisuzzman M, Hasan MM, Acharzo AK, Das AK, Rahman S (2017) In vivo and In vitro evaluation of pharmacological potentials of secondary bioactive metabolites of Dalbergia candenatensis leaves. Evid Based Complement Alternat Med. https://doi.org/https://doi.org/10.1155/2017/5034827

41. Rafe MR (2017) A review of five traditionally used anti-diabetic plants of Bangladesh and their pharmacological activities. Asian Pac J Trop Med 10 (10):933-939 https://doi.org/https://doi.org/10.1016/j.apjtm.2017.09.002.

42. Khatun MH, Nesa ML, Islam R, Ripa FA, Mamun A, Kadir S (2014) Antidiabetic and anti-diarrheal effects of the methanolic extract of Phyllanthus reticulates leaves in mice. Asian Pac J Reprod 3:121-127. https://doi.org/https://doi.org/ 10.1016/S2305-0500(14)60015-4.

43. Naher S, Aziz MA, Akter MI, Rahman SMM, Sajon SR, Mazumder K (2019) Anti-diarrheal activity and brine shrimp lethality bioassay of methanolic 
extract of Cordyline fruticosa (L.) A. Chev. leaves. Clinical Phytosci 5:15. https://doi.org/https://doi.org/10.1186/s40816-019-0109-z.

44. Hasan T, Sultana M (2018) Antidiabetic potency of Bangladeshi medicinal plants. J Ayu Herb Med 4(1):35-42

45. Akkol EK, Dereli FTG, Ilhan M (2019) Assessment of antidepressant effect of the aerial parts of Micromeria myrtifolia Boiss. \& Hohen on Mice. Molecules 24 (10) https://doi.org/https://doi.org/10.3390/molecules24101869.

46. Priyanka B, Sridhar Y, Shankaraiah P (2012) Antidepressant and muscle relaxant activity of Cardiospermum halicacabum Linn. Roots in mice. J Adv Pharm Sci 2(1):193-200

\section{Publisher's Note}

Springer Nature remains neutral with regard to jurisdictional claims in published maps and institutional affiliations.

\section{Submit your manuscript to a SpringerOpen ${ }^{\circ}$ journal and benefit from:}

- Convenient online submission

- Rigorous peer review

- Open access: articles freely available online

- High visibility within the field

- Retaining the copyright to your article

Submit your next manuscript at $\boldsymbol{\nabla}$ springeropen.com 